\title{
Characterization and diagnosis of the process of reuse of electronic waste: case study in a specialized center in Recife, Pernambuco, Brazil
}

\author{
Caracterização e diagnóstico do processo de reaproveitamento de resíduos \\ eletroeletrônicos: estudo de caso em centro especializado na cidade de \\ Recife, Pernambuco, Brazil
}

Paulo Henrique Ribeiro Ferraz'

\begin{abstract}
The expansion of the electro-electronic products market in Brazil, which occurred in the last decades, resulted in a higher volume of waste from electro electronic equipment (WEEE) generated due to the reduction of the useful life of the devices, having been the seventh largest generator of electronic waste in the country. in 2016. In Recife, an annual generation of 9,841 tons is estimated. Besides having materials of slow degradation, there are also heavy metals in the composition of electronic waste, harmful to the environment and living beings when in high concentration. Some studies have observed the insufficiency of actions by society regarding the correct disposal of WEEE. This research consists of a descriptive case study of the operation dynamics and reception rates of a specialized WEEE recycling center located in Recife, with collection points distributed throughout the city. Data from the first half of 2019 were analyzed. The study found the potential for reuse of donated equipment, as well as a greater contribution from the private sector, possibly reflecting the implementation of the National Solid Waste Policy.
\end{abstract}

Keywords: Electro-Electronic Waste; Reverse logistic; Electronic waste; E-waste

'Master's student in Environmental Engineering, Federal Rural University of Pernambuco, Recife, Pernambuco, Brazil - paulo.rferraz88@gmail.com 


\section{Introduction}

The constant technological evolution, combined with greater ease of access to electronic equipment, its popularization and the practice of consumerism, has resulted in a growth of this market in Brazil in recent decades. Consequently, such expansion caused the increase in the volume of solid waste from such products due to the reduction of life of the devices and components marketed; these are called waste from electro electronic equipment (WEEE). According to the study conducted by Mello et al (2016), a high consumption of electronic products by society was verified, usually driven by the media.

According to The Global E-waste Monitor (BALDÉ et al, 2017), Brazil was the second largest electronic waste generator in the American continent in 2016, with approximately 1.5 million tons, second only to the United States, which produced 6.3 million tons.

According to Lima et al (2015), the main problem of improper disposal of this type of residue occurs due to its composition where, in addition to containing materials such as glass, plastic and metal, which remain in nature for a long period; toxic metals such as nickel, copper, cadmium and lead are found, which contaminate the environment and harm living beings when at high concentration, through bioaccumulation in organisms. Lima et al (2015) still found, in his study, high levels of cadmium, copper and nickel in cell phone batteries; stating, moreover, that the efficiency of recycling processes has not progressed simultaneously to the growth of the consumption of electronic equipment. Rodrigues et al (2015) states that although the WEEE presents complexity due to its generation in a diffuse way and the presence of dangerous substances, it presents the possibility of recovery.

It is noteworthy that the implementation and structuring of reverse logistics systems for electro-electronic products and their components are mandatory independently of the public urban cleaning and industrial waste service, as determined by the National Solid Waste Policy (BRAZIL, 2010). Even so, its implementation still faces major obstacles, such as lack of awareness of the population and the effects generated by the excessive use of WEEE, 
as well as the absence of public policies. Demajorovic and Migliano (2013) highlighted some difficulties for the implementation of WEEE reverse logistics programs in Brazil, such as a continental scale of the country, a lack of tax incentives, a wide supply of orphan products and the presence of various actors involved. Selpis, Castilho and Araújo (2012) pointed out that besides Brazil, the growth of the consumption of technological products in relation to their recycling capacity was not followed, there is a need to make society aware of the correct destination of electronic waste, since most disconnect or ignore the danger of improper performance. Mello, Mayer and Costa (2016) highlighted a small number of WEEE collection and disposal centers in Brazil, most of them located in the state of São Paulo. As noted by Pereira, Ferraz and Massaini (2014), an understanding of respect for the correct disposal of electronic waste is widespread; however, they are few as actions by society.

In this scenario, knowledge of the process for proper disposal of WEEE becomes important. Thus, this work aims to map the reverse logistics process and the flow of electronic waste at the studied site.

\section{Theoretical Review}

\subsection{Overview of Electronic Waste Generation}

The disposal of urban waste is one of the main environmental problems of today, and, especially in large cities, there is concern about where to dispose of waste (SANTOS \& SOUZA, 2010).

The publication The Global E-waste Monitor (BALDÉ et al, 2017) verified the generation of 1.534 million tons of electronic waste in Brazil in 2016, at a rate of $7.4 \mathrm{~kg}$ per inhabitant, which earned it the position of largest generator. America's WEEE and the second largest generator on the American continent, as shown in figure 1. It is also added that Brazil

was the seventh largest producer of electronic waste in the world, and that the rate of collection of electronic waste in 2016, in all Latin American countries except Mexico, was below 3\%; that is, less than 3\% of electronic waste is collected and recycled (BALDÉ et al, 2017). 
Figure 1 - Electronic generation in the American continent, in 2016

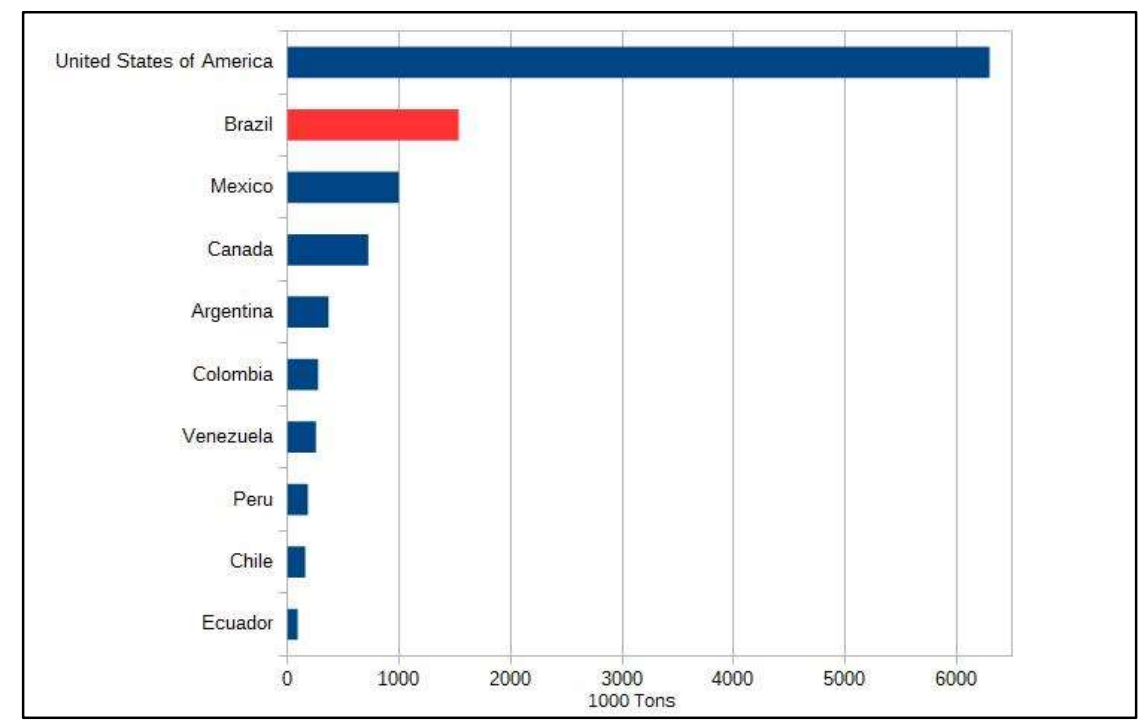

Source: Adapted from Baldé et al (2017)

Technological advances and the accelerated growth of the electronics market in Brazil have resulted in a progressive rate of generation of electronic waste (SANTOS \& SOUZA, 2010; FRANCE \& BARROS, 2013). The Brazilian Agency for Industrial Development (ABDI, 2013) points out that such growth is due to the expansion of the domestic market, as well as credit incentives, specific exemptions in taxation and changes in society's behavior. The National Household Sample Survey, conducted by the Brazilian Institute of Geography and Statistics (IBGE) from 2001 to 2015, found a growth in households with certain appliances, computers, and telephones, as shown in Figure 2.

(Continue...) 
Figure 2 - Evolution of access to certain appliances in private households

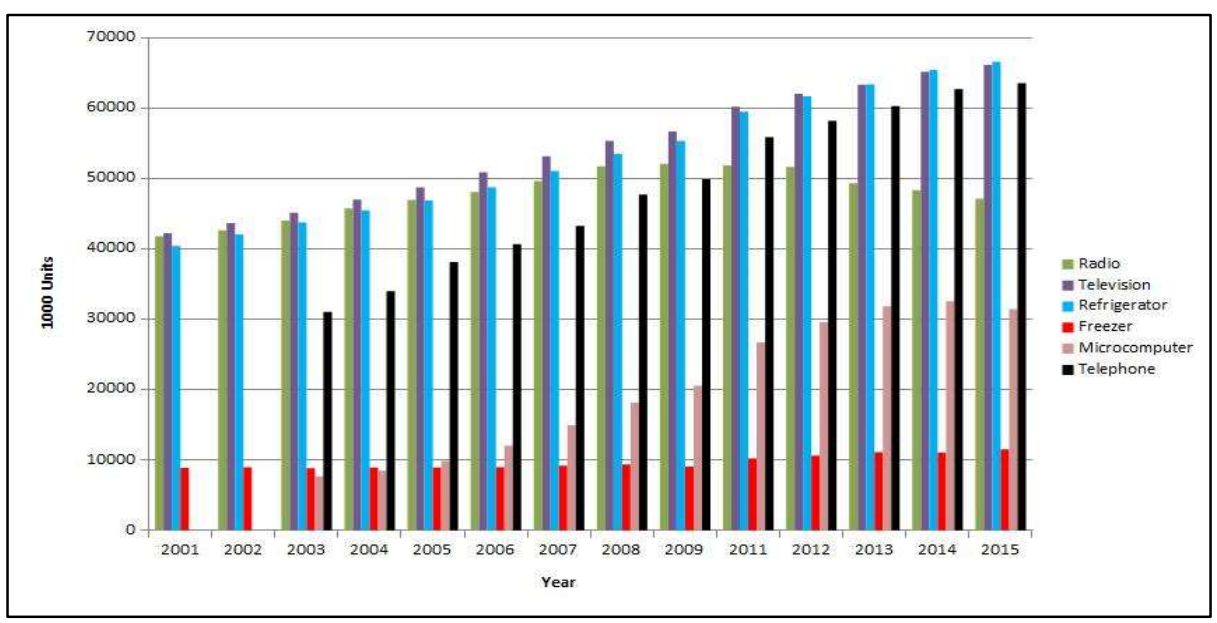

Source: adapted from IBGE (2001, 2002, 2003, 2004, 2005, 2006, 2007, 2008, 2009, 2011, 2012, 2013, 2014, 2015)

The estimated generation of electronic waste by 2020 is shown in Figure 3, according to the study published by ABDI (2013). It was considered as large WEEE those coming from white category (refrigerators, stoves, washing machines and air conditioning) while small equipment scans are located as TV/monitor, LCD/plasma, DVD/NHS, audio products, desktop, notebooks, printers, mobile phones, mixer, blender, electric iron and drill (ABDI, 2013).

Figure 3 - Estimated WEEE generation in Brazil

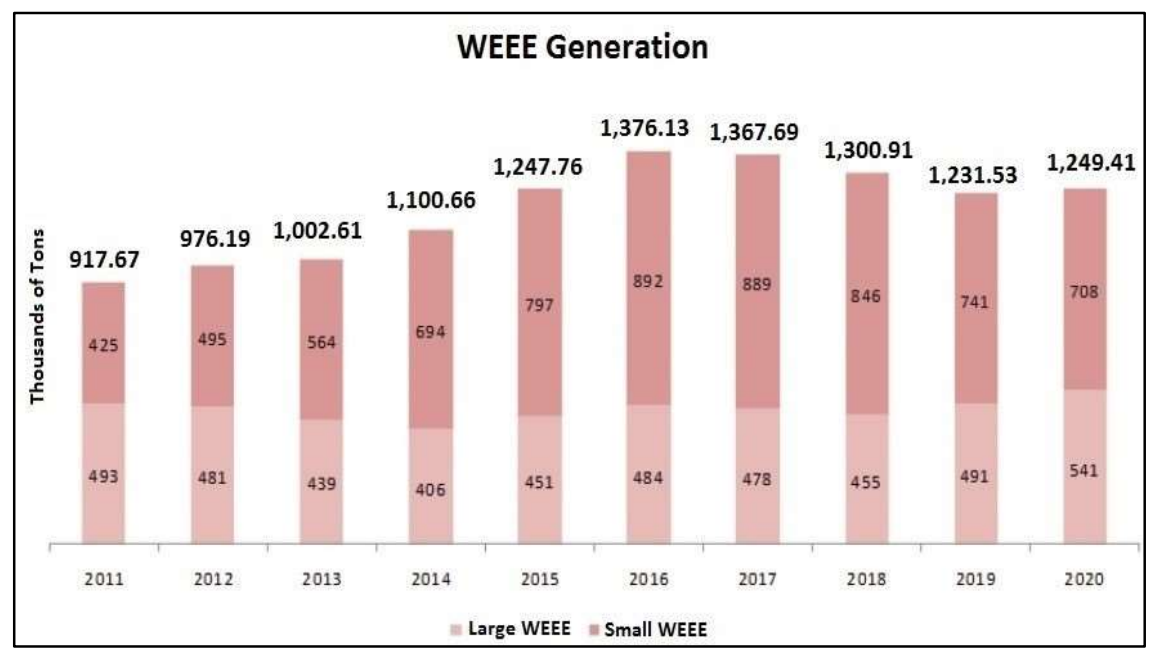

Source: ABDI (2013)

In the Metropolitan Development Region (MDR) of Pernambuco, it is estimated the generation of 23,636t / year of electronic waste, with an average estimate of 2,000 $\mathrm{t} / \mathrm{month}$, 
of which $9841 \mathrm{t} /$ year and $820 \mathrm{t} /$ month in Recife (PERNAMBUCO, 2015, 2018). A study conducted in 2016, in the Pernambuco State MDR, estimated the generation of WEEE in the region, as indicated until the year 2035 , based on the population growth estimate, as shown in figure 4 (PERNAMBUCO, 2016).

Figure 4 - Estimation of WEEE generation in the Pernambuco Metropolitan Development Region, until 2035

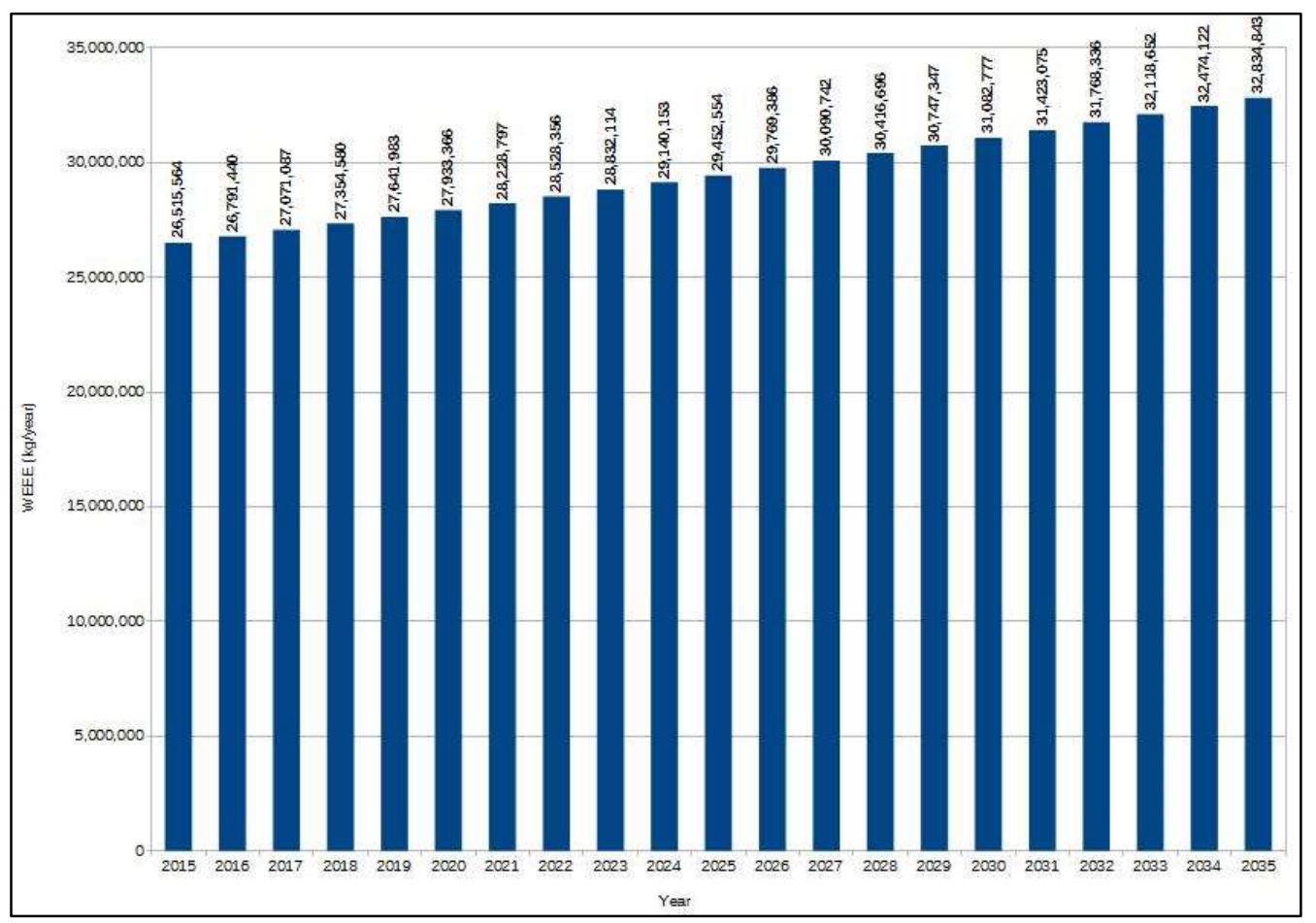

Source: Adapted from Pernambuco (2016)

The survey conducted by Franco and Lange (2011) in the city of Belo Horizonte (MG), in private households, found that only $2 \%$ of users dispose of cell phones for recycling, after the end of the first useful life; while none of the consumers dispose of obsolete TV sets, computers and refrigerators for recycling. Lavez, Souza and Leite (2011) observed, in their study, a derisory return of computers for recycling by individuals, alleged for the absence of specific reverse logistics for this source; where the greatest collaboration comes from the business sector. Kunrath (2015) found, in his study conducted in institutions located in the states of São Paulo and Rio Grande do Sul, a greater participation coming from industry (41.25\%), commerce (27.5\%) and households (18.75\%), regarding the disposal of WEEE. 
Pereira, Ferraz and Massaini (2014) conducted a study with students from a university in the northeastern region of the country, where there was a positive evaluation in the questions about strategic actions of companies, benefits of recycling and their motivation; while the questions about the recycling practice and the presence of collection points were evaluated inferior to the previous ones, thus evidencing the insufficiency of the actions by the society.

A survey by Gama, Vasconcellos and Machado (2016) was also conducted on the Manaus campus of the Federal Institute of Amazonas (IFAM), showing that $83 \%$ of respondents say they are aware of the risks regarding the inappropriate disposal of WEEE and would like to contribute, Ninety-five percent said they had an interest in disposing of electronic waste at separate collection points, $80 \%$ said they would be willing to pay more for an environmentally friendly product, while only $41 \%$ know about separate collection sites.

\subsection{Reverse Logistics}

The National Solid Waste Policy defines reverse logistics as "an economic and social development instrument characterized by a set of actions, procedures and means designed to enable the collection and return of solid waste to the business sector, for reuse, in its cycle or in other production cycles, or other environmentally appropriate final destination" (BRAZIL, 2010).

Natume and Sant'Anna (2011) state that reverse logistics provides the return of waste to the business sector, improving the practice of waste reduction, reuse and reuse. Mello, Mayer and Costa (2016) point out that the recycling process involves four phases: material collection and transportation, separation and cleaning, reprocessing and manufacturing of new products and their commercialization. The authors also verified, in their study carried out at an institute in the city of São Paulo, that reverse logistics is only used in situations when it is impossible to reuse or recycle the items.

It is known that the implementation of reverse logistics system can bring not only environmental, but also social and economic benefits, having been listed by ABDI (2013) in Table 1. 
Table 1 - Benefits of Reverse Logistics System

\begin{tabular}{|c|c|c|}
\hline Social & Economic & Environmental \\
\hline Formal job generation & $\begin{array}{l}\text { Higher return to } \\
\text { market for WEEE } \\
\text { recycling raw } \\
\text { materials }\end{array}$ & $\begin{array}{l}\text { Decrease in incorrect } \\
\text { WEEE disposal cases }\end{array}$ \\
\hline $\begin{array}{l}\text { Strengthening waste } \\
\text { pickers associations with } \\
\text { generation of } \\
\text { opportunities to provide } \\
\text { services to the system }\end{array}$ & $\begin{array}{l}\text { Strengthening of the } \\
\text { recycling industry by } \\
\text { the consequent } \\
\text { increase in demand }\end{array}$ & $\begin{array}{l}\text { Improved quality of } \\
\text { recycling services and } \\
\text { consequent lower } \\
\text { level of landfill waste }\end{array}$ \\
\hline $\begin{array}{l}\text { Promoting greater } \\
\text { awareness of the } \\
\text { population regarding } \\
\text { environmental issues } \\
\text { related to electronic } \\
\text { equipment }\end{array}$ & $\begin{array}{c}\text { Knowledge and } \\
\text { technology } \\
\text { development related } \\
\text { to WEEE recycling }\end{array}$ & $\begin{array}{l}\text { Energy expenditure } \\
\text { reduction due to } \\
\text { recycled use }\end{array}$ \\
\hline $\begin{array}{l}\text { Minimization of health } \\
\text { problems caused by } \\
\text { incorrect WEEE handling }\end{array}$ & & \\
\hline
\end{tabular}

Source: ABDI (2013)

According to ABDI (2013), for over 20 years, some states have already presented measures regarding WEEE, giving manufacturers, importers and traders responsibility for their collection and treatment, even though there is no national legislation and regulation that would allow the development of an infrastructure necessary for the treatment of this waste. ABDI (2013) also points out that the late industrialization, as well as the lack of public 
and media interest in environmental issues contributed to this situation. Demajorovic and Migliano (2013) state that the establishment of the National Solid Waste Policy (Law No. 12.305 / 2010) established a regulatory framework for society by establishing a system of shared responsibility for the life cycle of various products. The authors also highlight the establishment of the reverse logistics mechanism in order to provide the reuse of waste in the production chain and the environmentally appropriate disposal of their final tailings. However, according to the National Solid Waste Plan (BRAZIL, 2012), a sectoral agreement, also defined by Law No. 12,305 / 2010, will be required for the implementation of the reverse logistics plan. Currently, a proposal for a sectoral agreement between the Union and entities representing the companies operating in the sector is currently under public consultation, aiming at the implementation of a reverse logistics system for electro-electronic products inserted in the national market. In the state of Pernambuco, the publication "Manual para destinação: orientação ao consumidor sobre como e onde destinar seus resíduos" (LUNA, 2018), elaborated by the Secretariat of Environment and Sustainability, lists some of the places available for disposal. or delivery of electro-electronic equipment.

In the study by Kunrath (2015), in the states of São Paulo and Rio Grande do Sul, it was found that only $33 \%$ of the entities reported performing WEEE recovery procedures. The author also verified the recyclable percentage of each waste as indicated in figure 5; still stating that $80 \%$ of the total material collected is recyclable on average.

Figure 5 - Recyclable portion by waste group in companies located in RS and SP

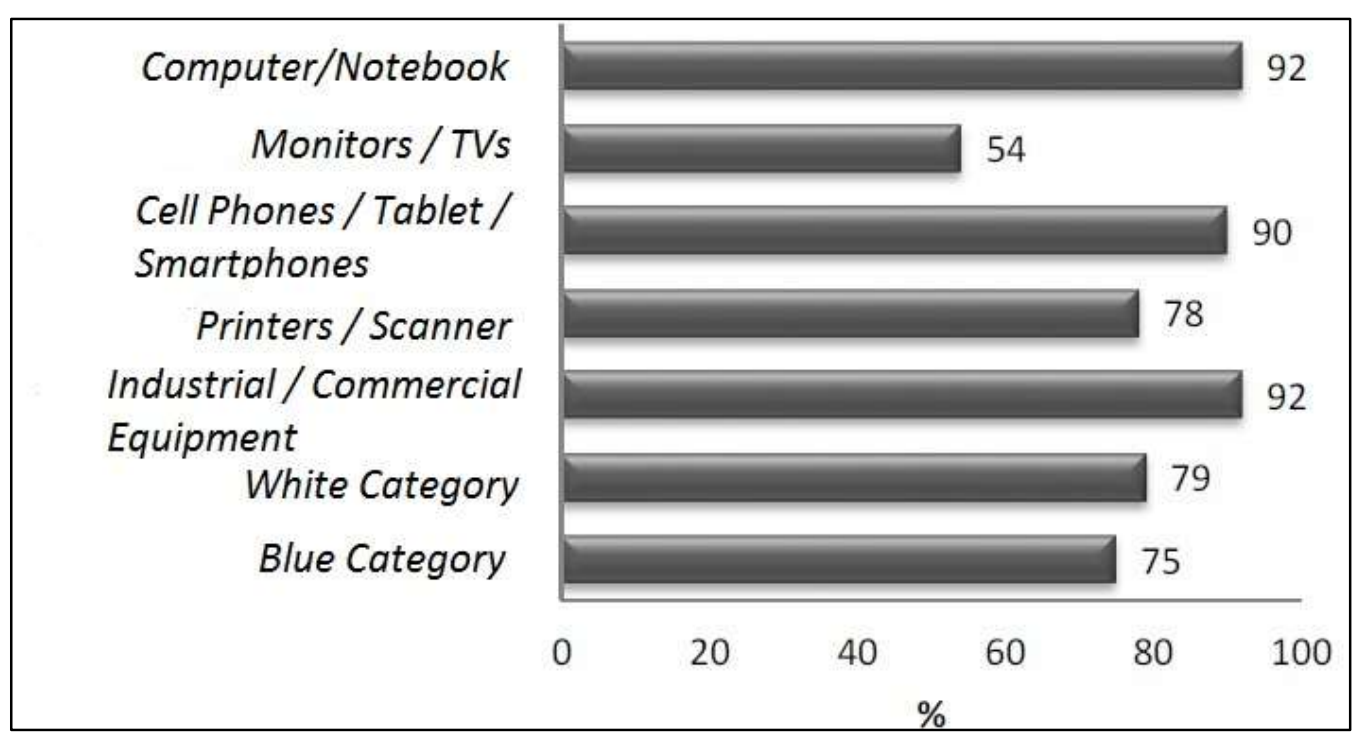


Source: Kunrath (2015)

Lavez, Souza and Leite (2011) reported the transportation cost relevance in their research, due to the low value of the transported product, being feasible only the short distance collections and by road mode. The authors also highlighted the lower levels of organization and relationship between the links involved in the reverse logistics chain.

Selpis, Castilho and Araújo (2012) point out that although reverse logistics is considered an efficient tool in waste management, there are barriers such as high transportation costs due to lack of infrastructure, poor road maintenance, among other problems, which interferes with the cost of recycling; also highlighting the need for joint effort between society, companies and the state, as well as easily accessible collection points, logistical conditions and tax incentives.

\section{Methodology}

It will be used the case study of descriptive approach as a research tool, which observed the steps for the proper disposal of electronic waste, with the objective of mapping all the steps and procedures performed, and to verify the reusable and recyclable portions of WEEE, the potential for reuse of this type of waste can be verified. According to Yin (2001), the case study is the strategy most used when raising questions such as "how" and "why"; enabling an analysis that seeks to maintain the comprehensive and significant characteristics of real life events, such as organizational and administrative processes, among others. André (1984) points out that case study is a type of investigation that emphasizes the understanding of particular events. According to Zanella (2011), the descriptive research "seeks to know the reality studied, its characteristics and its problems". Vergara (1998) states that the descriptive approach highlights characteristics of the population or phenomenon studied and may establish the nature of the variables and their correlations; however, it does not undertake to explain the phenomena described.

Because the activities performed by the company consisted of a major player involved in the process and also its significant performance in the city, it was decided to study its 
operating dynamics, raising, in loco, all stages of the process, observing the control criteria, as well as the verification of the flow of electronic waste passing through the site and the characterization of donors.

\section{Results}

\subsection{Place of Study}

The study site consists of a center specializing in the reconditioning of electronic equipment, located in Recife / PE, with 19 collection points in the Metropolitan Region, 18 of them in Recife / PE. Its coverage area comprises a radius of $12 \mathrm{~km}$ and a route of $20 \mathrm{~km}$, considering the most distant collection point.

The center is responsible for receiving, sorting and reconditioning the electroelectronic equipment, as well as for the segregation of its components for subsequent referral to recycling, given the impossibility of recovery. Currently, equipment is received from all categories, as divided by ABDI (2013), in: green, brown, white and blue.

\subsection{Processo Mapping}

Figure 6 - Waste weighing place

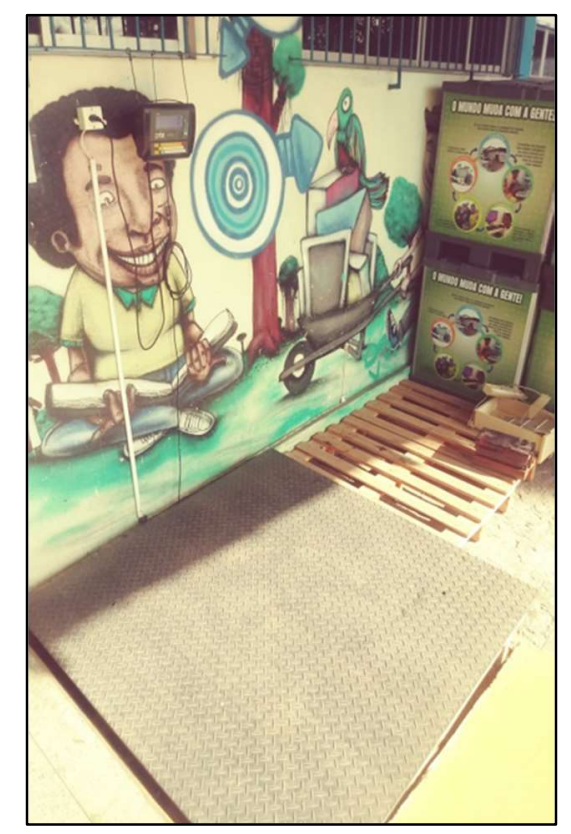

Source: Author 
Upon arrival at the center, the waste is weighed and then segregated into plastic drums and containers, where components are distinguished by typology and routed to the place where remanufacturing takes place, while equipment is stored in a specific sorting room, being separated by segment type.

Figure 7 - Component segregation

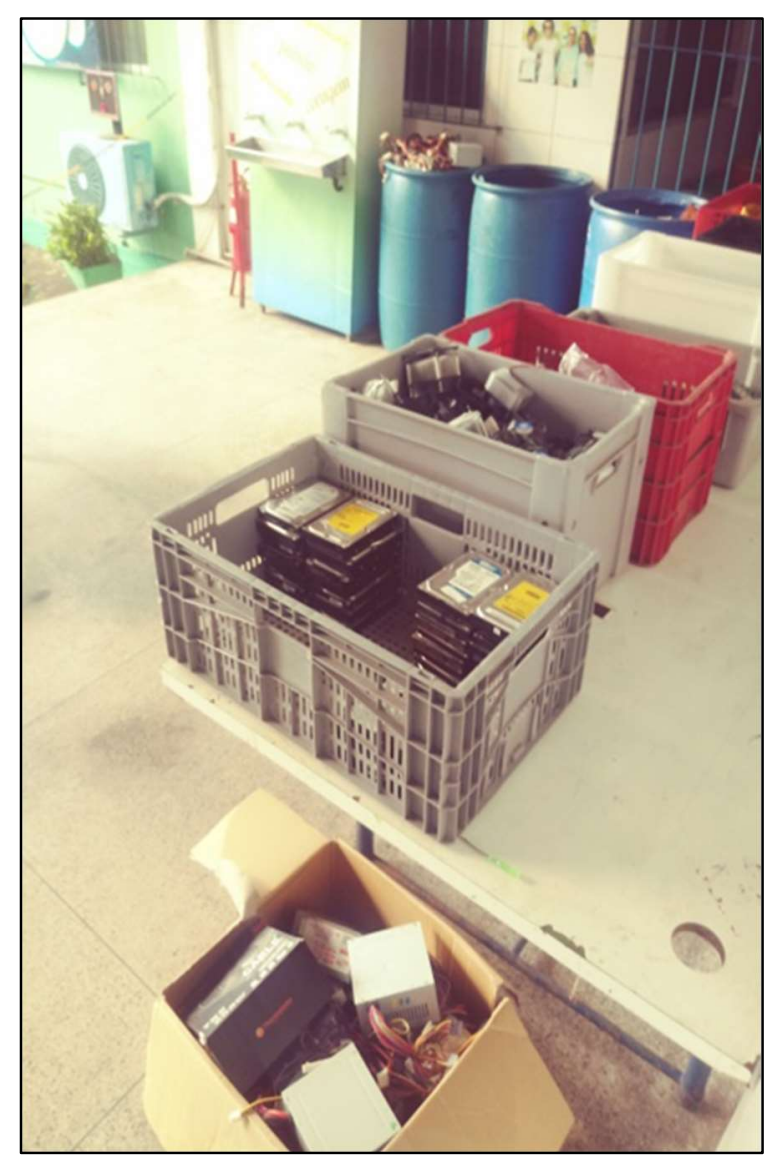

Source: Author

In the sorting room, all equipment is tested, receiving the green stamp when it is functioning normally, yellow when it has problems, and red when it does not work.

(Continue...) 
Figure 8 - Equipment storage in the sorting room

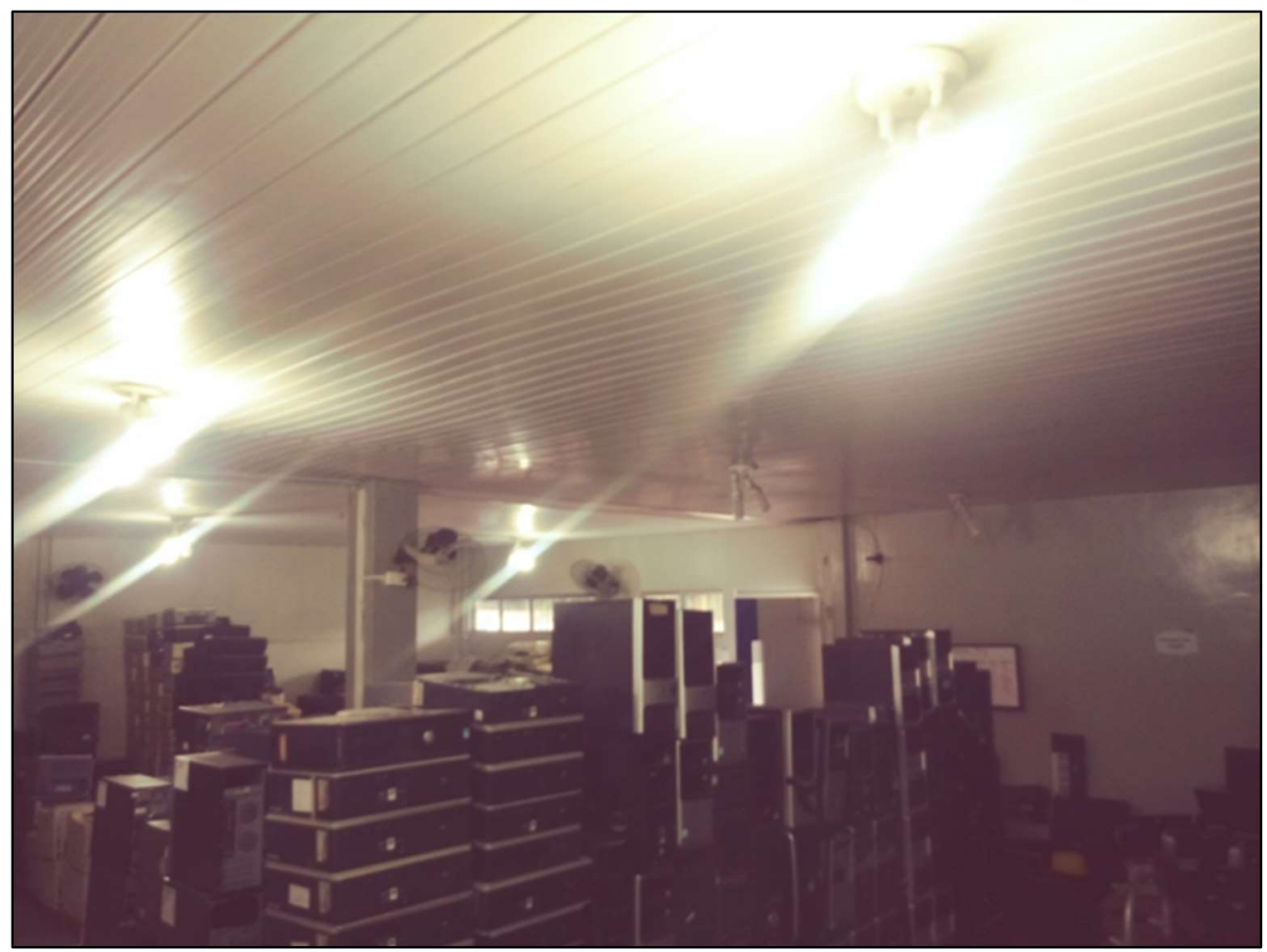

Source: Author

Figure 9 - Printer sorted after test

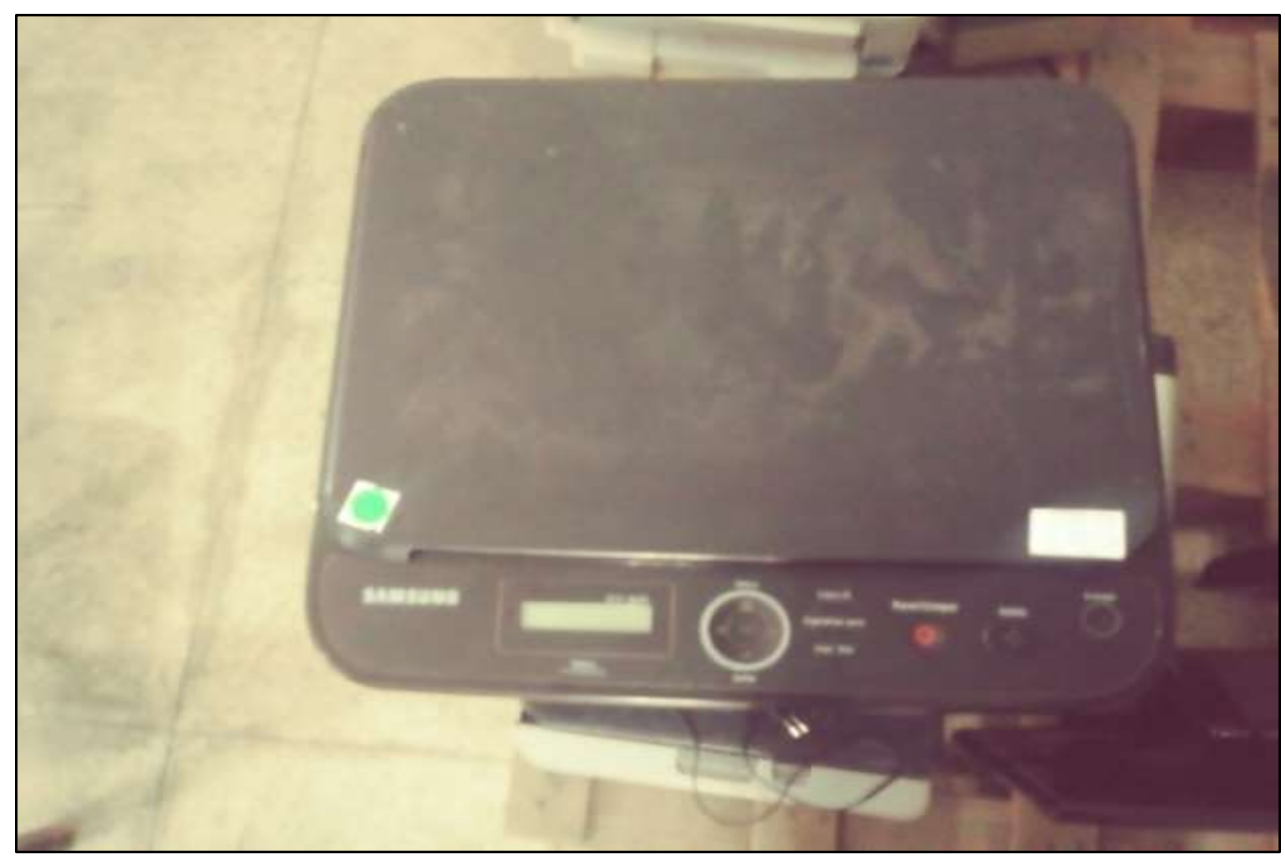

Source: Author

Figure 10 - Monitor sorted after test 


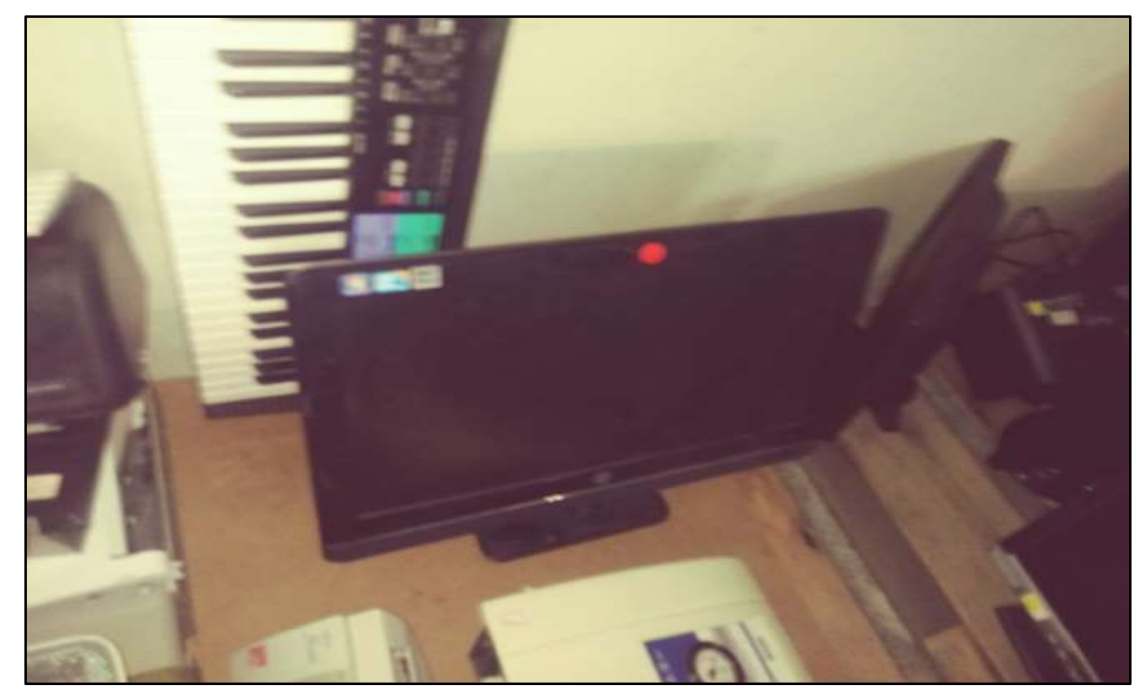

Source: Author

The equipment that receives yellow and red stamp are forwarded to remanufacturing, with the purpose of evaluating the possibility of reconditioning, using the components derived from disposal as any spare parts, depending on their conditions of use. Remanufactured equipment, together with those receiving green stamp in the initial sorting, are forwarded for sale/donation; while those without reuse conditions are disassembled and subsequently separated each component and stored in a specific location to then be intended for recycling, which is carried out by specific companies for this purpose.

Figure 11 - Reconditioning Room

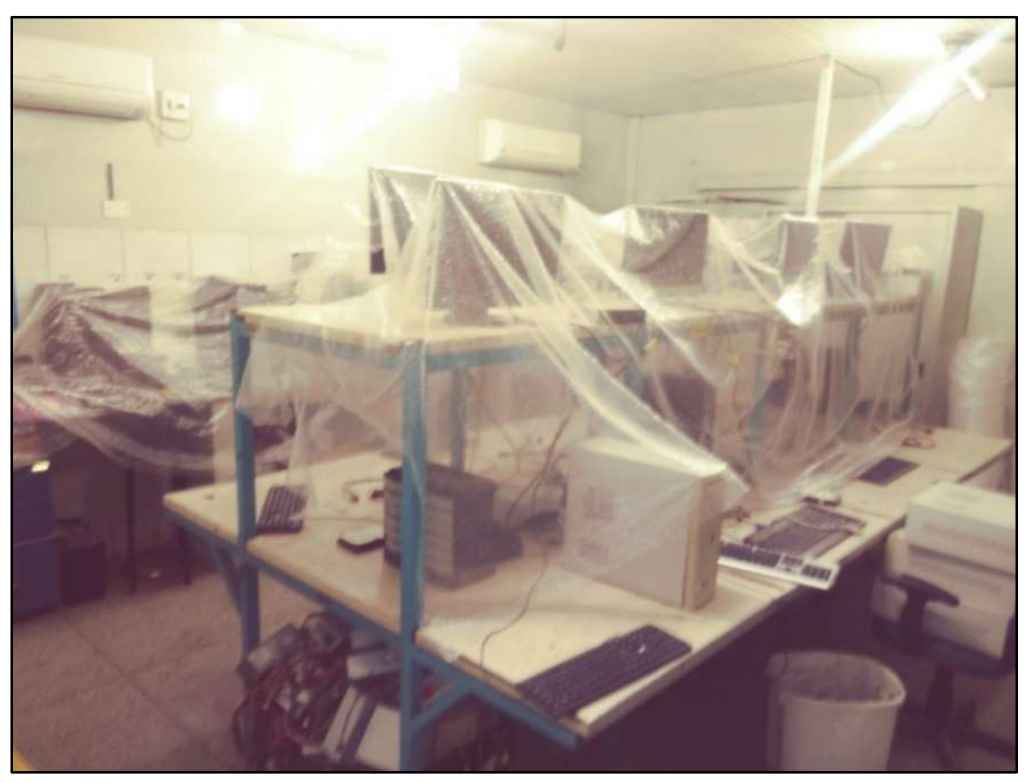


Source: Author

Figure 12 - Reconditioning Room

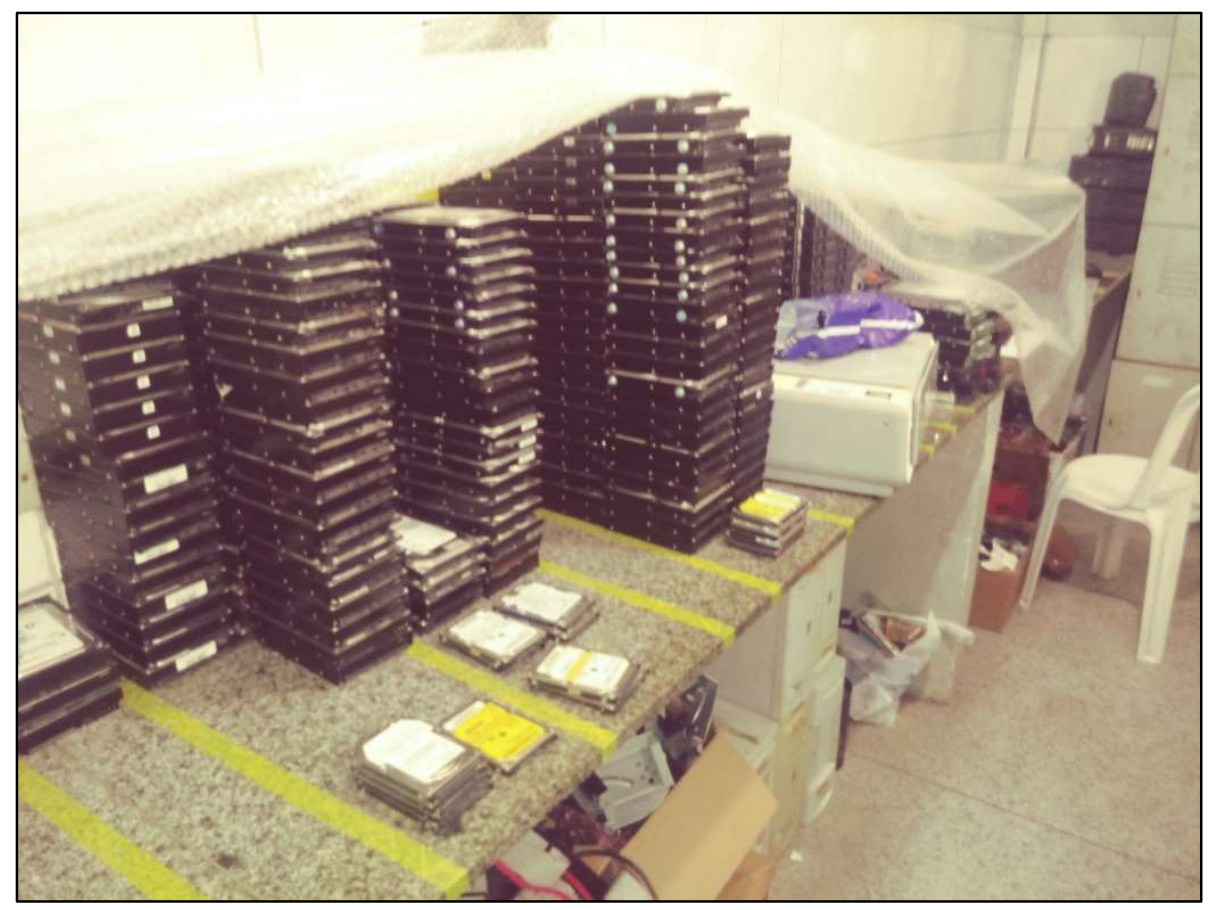

Source: Author

Figure 13 - Storage of computer cases for later shipment to recycling

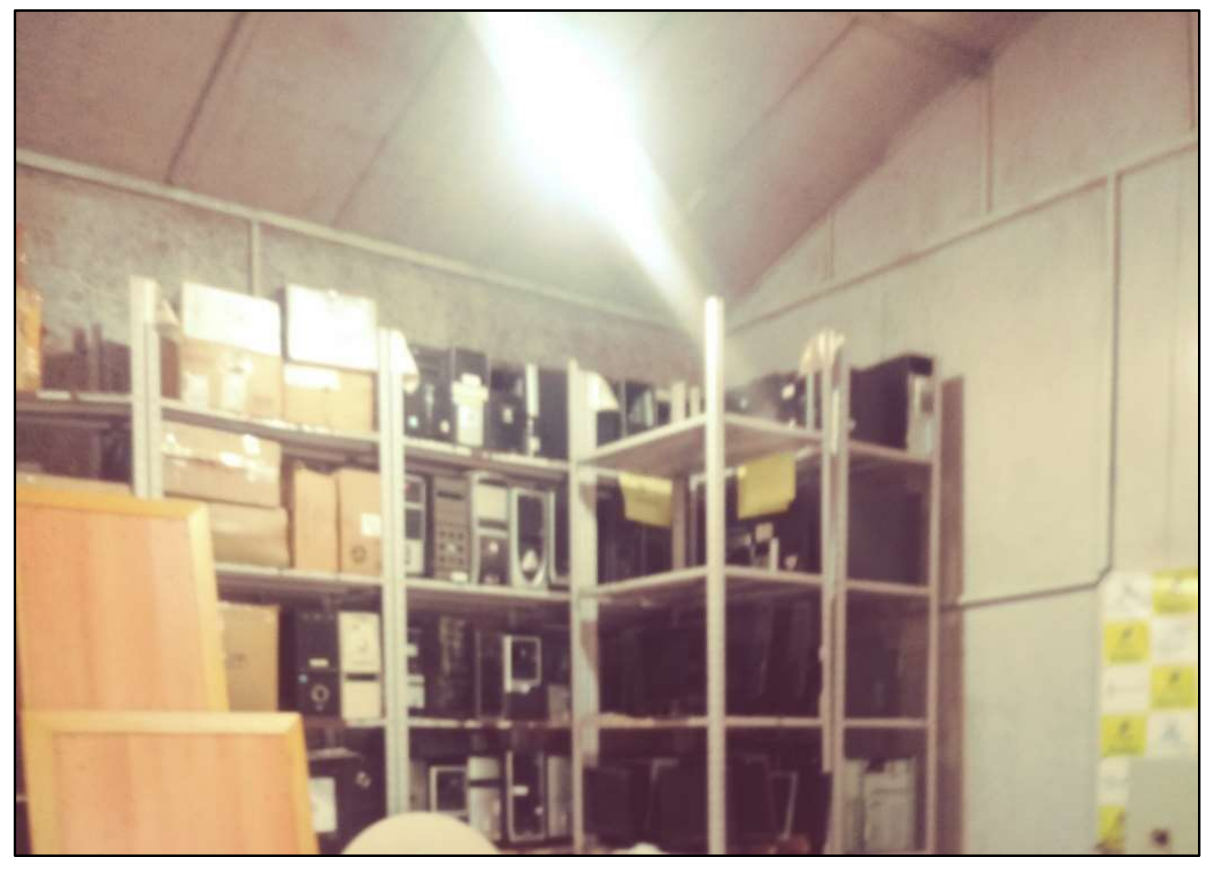

Source: Author

All stages of the reverse logistics process practiced by the company are described in the flowchart of figure 14 . 
Figure 14 - Activity flow adopted by the company

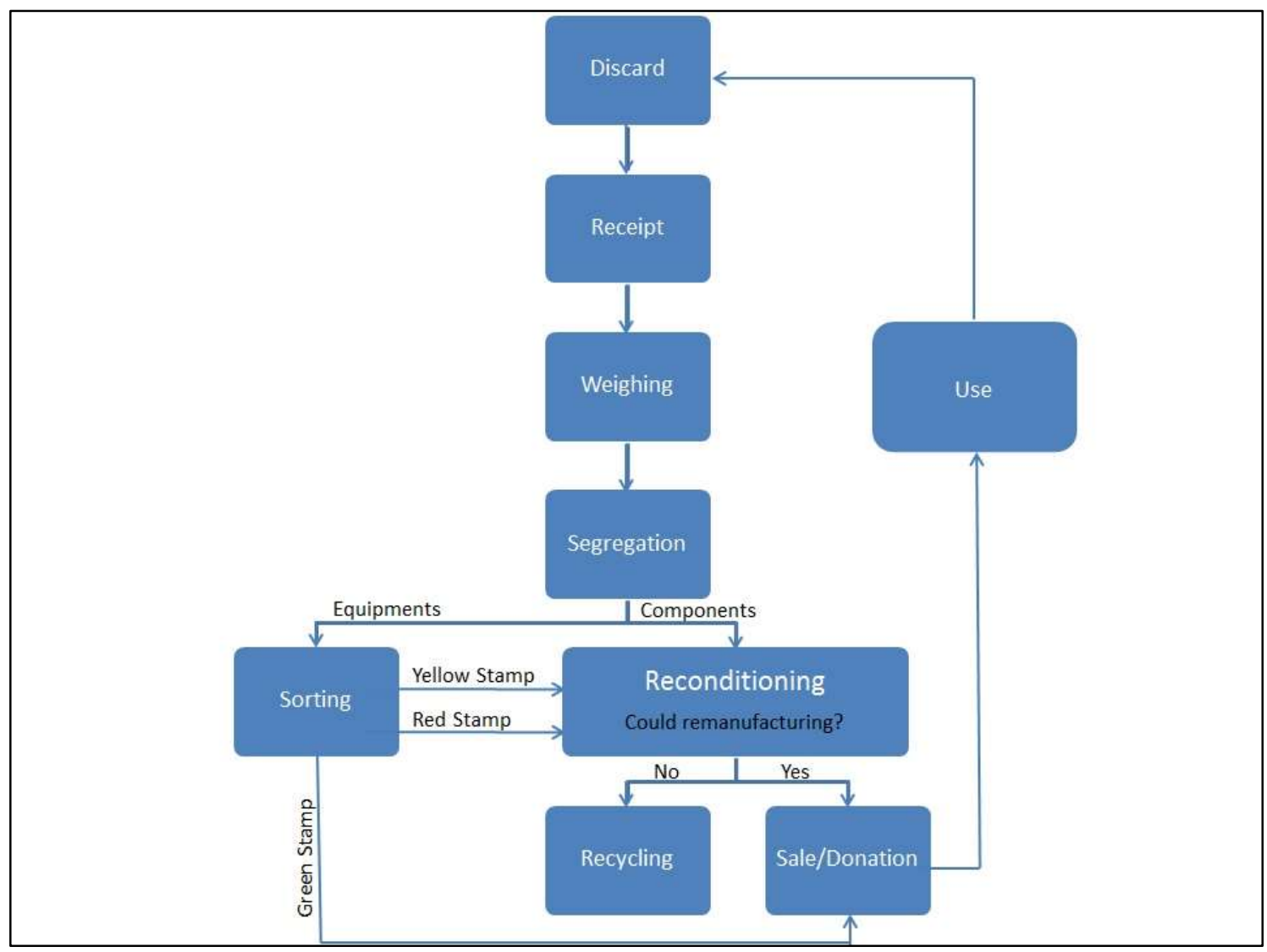

Source: Author

\subsection{Donation and Waste Receipt Overview}

Data of the first half of 2019 were analyzed, where a flow of approximately $22,000 \mathrm{~kg}$ of discarded equipment was verified, equivalent to $0.45 \%$ of the estimated production for the municipality of Recife in one semester. There was a higher incidence of donations related to computer equipment, belonging to the green and brown lines, representing $67.52 \%$ of the donated units in the period, highlighting the devices indicated in table 2. It is worth mentioning that the institution claimed to have refurbished and donated 400 computers between 2018 and 2019, which is approximately 78\% of the number of CPUs received in the first half of 2019.

(Continue...) 
Table 2 - Incidence of equipment receipts in the first half of 2019

\begin{tabular}{ll}
\hline Equipments & Percentage \\
\hline Mouse & $11,50 \%$ \\
\hline Cables & $10,90 \%$ \\
\hline Keyboard & $10,56 \%$ \\
\hline CPU & $9,20 \%$ \\
\hline LCD Monitor & $9,11 \%$ \\
\hline Printers & $7,07 \%$ \\
\hline Stabilizer & $3,59 \%$ \\
\hline Speaker & $2,25 \%$ \\
\hline Notebooks & $2,02 \%$ \\
\hline CRT monitor & $1,32 \%$ \\
\hline TOTAL & $67,52 \%$
\end{tabular}

Source: Author

It was also found that the largest contribution of donations in the period studied came from legal entities, followed by individuals and, finally, public agencies, as described in the graph in Figure 15.

(Continue...)

Figure 15 - Receiving index by supplier type

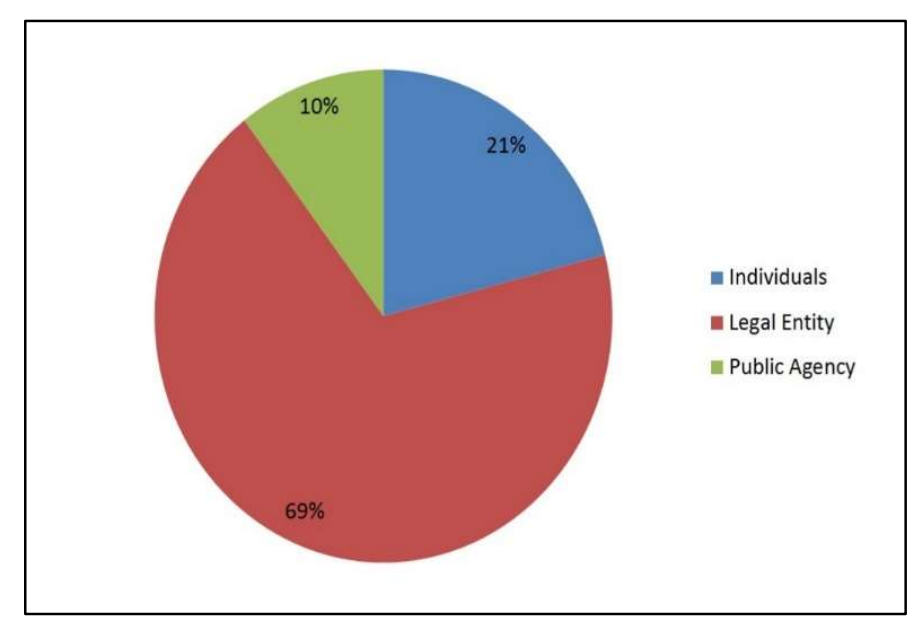

Source: Author 


\section{Conclusions}

Because the company's collection points cover most of the city of Recife, the information extracted through the available data can provide an overview of the collection and treatment of electronic waste in the city of Recife. The potential for reuse of discarded electronic equipment through remanufacturing was also observed. However, as most of the donated devices consist of computer equipment, there are uncertainties regarding the current fraction of the correct disposal of electronic waste in the city, since in the research cited there was a growth in access to appliances of all categories in the last decades.

Regarding the profile of suppliers, the higher rate of donations from legal entities, in addition to the larger volume, is a possible reflection of the implementation of the National Solid Waste Policy (BRAZIL, 2010).

It is suggested for future studies a research on the awareness of the population of the city regarding the disposal of their electronic equipment after the end of its useful life, as well as the flow of WEEE in other recycling companies.

\section{References}

AGÊNCIA BRASILEIRA DE DESENVOLVIMENTO INDUSTRIAL. Logística Reversa de Equipamentos Eletroeletrônicos: Análise de Viabilidade Técnica e Econômica. Brasília: ABDI/Inventta Consultoria Itda, 2013. Available in: http://www.mdic.gov.br/arquivos/dwnl_1416934886.pdf. Access: September 21, 2019.

ANDRÉ, M.E.D.A. Estudo de caso: seu potencial na educação. 1984. Cad. Pesq.; (49): 51-54.

BALDÉ, C.P., FORTI V., GRAY, V., KUEHR, R., STEGMANN, P. The Global E-waste Monitor - 2017: Quantities, Flows, and Resources. Bonn/Geneva/Vienna: United Nations University (UNU), International Telecommunication Union (ITU) \& International Solid Waste Association (ISWA), 2017. Available in: http://ewastemonitor.info/. Access: September 16, 2019.

BRASIL. Lei no 12.305, de 2 de agosto de 2010. Institui a Política Nacional de Resíduos Sólidos; altera a Lei no 9.605, de 12 de fevereiro de 1998; e dá outras providências. Diário Oficial da União: Seção 1, Brasília, DF, year 147, p. 3-7, August 3, 2010.

BRASIL. MINISTÉRIO DO MEIO AMBIENTE. Plano Nacional de Resíduos Sólidos. Brasília: 2012. 
Available

https://sinir.gov.br/images/sinir/Arquivos_diversos_do_portal/PNRS_Revisao_Decreto_280812.pdf. Access: September 23, 2019.

BRASIL. MINISTÉRIO DO MEIO AMBIENTE. Consulta Pública Eletroeletrônicos. Acordo Setorial de Produtos Eletroeletrônicos e seus Componentes. Available in: http://consultaspublicas.mma.gov.br/eletroeletronicos/. Access: September 23, 2019.

DEMAJOROVIC, J. MIGLIANO, J.E.B. Política Nacional de Resíduos Sólidos e suas implicações na cadeia da logística reversa de microcomputadores no Brasil. Gestão \& Regionalidade. 2013; 29(87): 64-80.

FRANÇA, P.G., BARROS, L.R. Situação atual dos resíduos eletrônicos no Brasil. Revista Interface Tecnológica. 2017; 14(1): 96-104.

FRANCO, R.G.F., LANGE, L.C. Estimativa do fluxo dos resíduos de equipamentos elétricos e eletrônicos no município de Belo Horizonte, Minas Gerais, Brasil. Eng. Sanit. Ambient. 2011; 16(1): 73-82.

GAMA, E.F., VASCONCELLOS, J.M.S., MACHADO, A.L.S. A logística reversa do lixo eletrônico: um estudo de caso no Instituto Federal do Amazonas - Campus Manaus Distrito Industrial. Nexus Revista de Extensão do IFAM. 2016; 2(2): 61-69.

INSTITUTO BRASILEIRO DE GEOGRAFIA E ESTATÍSTICA. Pesquisa Nacional por Amostra de Domicílios 2001 a 2015. Available in: https://sidra.ibge.gov.br/pesquisa/pnad. Access: September 21, 2019.

KUNRATH, J.L. Resíduos eletroeletrônicos: um diagnóstico da cadeia de processamento [dissertation]. Porto Alegre: Escola de Engenharia/PPGE3M/UFRGS, 2015.

LAVEZ, N., SOUZA, V.M., LEITE, P.R. O papel da logística reversa no reaproveitamento do "lixo eletrônico"- um estudo no setor de computadores. Revista de Gestão Social e Ambiental. 2011; 5(1): 15-32.

LIMA, A.F.O., SABIÁ, R.J., TEIXEIRA, R.N.P., SOBREIRA JÚNIOR, F.A.V. Gestão de resíduos eletroeletrônicos e seus impactos na poluição ambiental. Latin American Journal of Business Management. 2015; 6(2): 109-126.

LUNA, A.D., organizer. Manual para destinação: orientação ao consumidor sobre como e onde destinar seus resíduos. 3rd ed. Recife: Ed. UFPE, 2018. Available in: http://www.semas.pe.gov.br/c/document_library/get_file?p_I_id=34251548\&folderld=34251651\&na me=DLFE -

234607.pdf. Access: September 24, 2019.

MELLO, A.P., MAYER, J.P.S., COSTA, K.A.S. Considerações sobre a destinação do lixo eletrônico. Revista REFAS. 2016; 2(3): 1-13.

NATUME, R.Y., SANT'ANNA, F.S.P. Resíduos Eletroeletrônicos: Um Desafio Para o Desenvolvimento Sustentável e a Nova Lei da Política Nacional de Resíduos Sólidos. 3rd International Workshop 
Advances in Cleaner Production; 2011, Maio 18-20; São Paulo; BR. São Paulo: UNIP, 2011.

PEREIRA, F.A.M.; FERRAZ, S.B.; MASSAINI, S.A. Dimensões de Consciência dos Consumidores no Processo de Reciclagem do Lixo Eletrônico (E-WASTE). Revista Gestão \& Tecnologia. 2014; 14(3): 177202.

PERNAMBUCO. SECRETARIA DAS CIDADES. Plano de resíduos sólidos: Região de Desenvolvimento Metropolitana de Pernambuco - RDM/PE. 2nd ed. Recife: Caruso Jr., 2018. Available in: http://www.seduh.pe.gov.br/web/secid/programas-acoes/consorcio-metropolitano-de residuossolidos. Access: September 16, 2019.

PERNAMBUCO. SECRETARIA DAS CIDADES. Plano de Resíduos Sólidos da Região de Desenvolvimento Metropolitana de Pernambuco, incluindo Programa de Coleta Seletiva. Produto 02 - Diagnóstico da Situação Atual dos Resíduos Sólidos da Região de Desenvolvimento Metropolitana de Pernambuco - PRS/RDM-PE. Recife: Caruso Jr., 2015. Available in: http://www.seduh.pe.gov.br/web/secid/programas-acoes/consorcio-metropolitano-de-residuossolidos. Access: September 16, 2019.

PERNAMBUCO. SECRETARIA DAS CIDADES. Plano de Resíduos Sólidos da Região de Desenvolvimento Metropolitana de Pernambuco, incluindo Programa de Coleta Seletiva. Produto 04 - Planejamento das Ações do Plano de Resíduos Sólidos. Recife: Caruso Jr., 2016. Available in: http://www.seduh.pe.gov.br/web/secid/programas-acoes/consorcio-metropolitano-de-residuossolidos. Access: September 16, 2019.

RODRIGUES, A.C., GUNTHER, W.M.R., BOSCOV, M.E.G. Estimativa da geração de resíduos de equipamentos elétricos e eletrônicos de origem domiciliar. proposição de método e aplicação ao município de São Paulo, São Paulo, Brasil. Eng. Sanit. Ambient. 2015; 20(3): 437-447.

SANTOS, F. H. S.; SOUZA, C. E. G. Resíduos de origem eletrônica. Rio de Janeiro: CETEM/MCT, 2010. Available in: http://mineralis.cetem.gov.br/bitstream/cetem/313/1/sta-57.pdf. Access: September 21, 2019.

SELPIS, A.N., CASTILHO, R.O., ARAÚJO, J.A.B. Logística reversa de resíduos eletroeletrônicos. Tékhne e Lógos. 2012; 3(2): 111-128.

VERGARA, S.C. Projetos e relatórios de pesquisa em administração. 2nd ed. São Paulo: Editora Atlas, 1998.

YIN, R.K. Estudo de caso: planejamento e métodos. 2nd ed. Grassi, D., translator. Porto Alegre: Bookman, 2001.

ZANELLA, L.C.H. Metodologia de Pesquisa. 2nd ed. revised and updated. Florianópolis: Departamento de Ciências da Administração/UFSC, 2011. 